$5-1-2020$

\title{
Bangladesh: COVID-19 knowledge, attitudes, practices and needs
}

Population Council

Follow this and additional works at: https://knowledgecommons.popcouncil.org/departments_sbsr-pgy

Part of the International Public Health Commons, Public Health Education and Promotion Commons, and the Social and Behavioral Sciences Commons

How does access to this work benefit you? Let us know!

\section{Recommended Citation}

"Bangladesh: COVID-19 knowledge, attitudes, practices and needs," COVID-19 Research \& Evaluations presentation. Dhaka: Population Council, 2020. 


\section{POPULATION}

\section{COUNCIL}

Ideas. Evidence. Impact.

\section{BANGLADESH: COVID-19}

KNOWLEDGE, ATTITUDES,

PRACTICES \& NEEDS

May 2020 


\section{Background}

- The first COVID-19 positive patient in Bangladesh was reported on 8 March 2020 by the Institute of Epidemiology, Disease Control \& Research (IEDCR)

- On 18 March 2020, the Ministry of Education (MoE) of Bangladesh declared school closures of all educational institutions

- From 26 March 2020, the first 10-day long nationwide 'holiday' was declared by the government, including a ban on all passenger travel via water, rail, and domestic air routes during this period, which ultimately continued until the end of May 2020 


\section{Overview: Data collection}

Phone-based survey conducted between

20-30 April 2020

- Location: Project areas of Bogura, Jamalpur, Sherpur, Kushtia and Chapainawabganj districts

- Sample: Sample from Bogura and Jamalpur represents all the adolescent girls in program area. The rest are a random sample of program-enrolled girls

- Respondents: 959 adolescent girls

- Success rate: $68 \%$

- Average interview time: 22 minutes 


\section{Background characteristics}

\begin{tabular}{|l|c|}
\hline Indicators & Percentage \\
\hline Age group & \\
\hline $10-12$ years & $9 \%$ \\
\hline $13-15$ years & $57 \%$ \\
\hline $16-18$ years & $27 \%$ \\
\hline 19-21 years & $7 \%$ \\
\hline Average age (years) & 15 years \\
\hline Schooling status & \\
\hline In school & $81 \%$ \\
\hline Out-of-school & $19 \%$ \\
\hline Marital status & \\
\hline Unmarried & $88 \%$ \\
\hline Married & $12 \%$ \\
\hline N & 959 \\
\hline
\end{tabular}




\section{Process of data collection}

- Structured questionnaire administered via smart phone with SurveyCTO software

- 11 interviewers trained through Facebook messenger and WhatsApp

- Consent taken through SMS by the respondents 


\section{Knowledge on symptoms, transmission and prevention}




\section{What are the symptoms of COVID-19?}

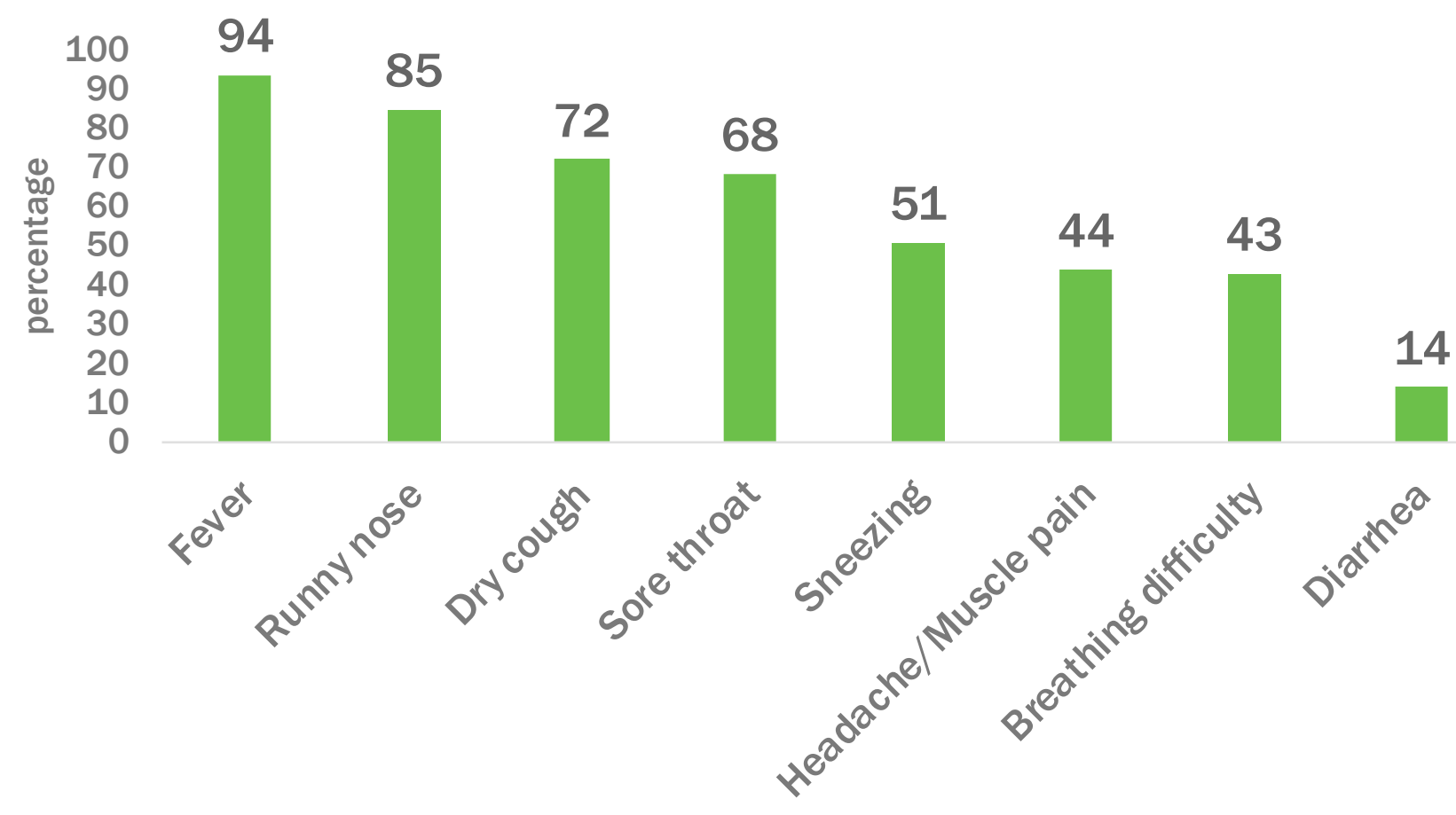

Fever, dry cough and sore throat correctly identified as major symptoms by adolescent girls

Difficulty breathing
being a serious
symptom was
identified by a small
percentage of the
adolescent girls




\section{How can COVID-19 be prevented?}

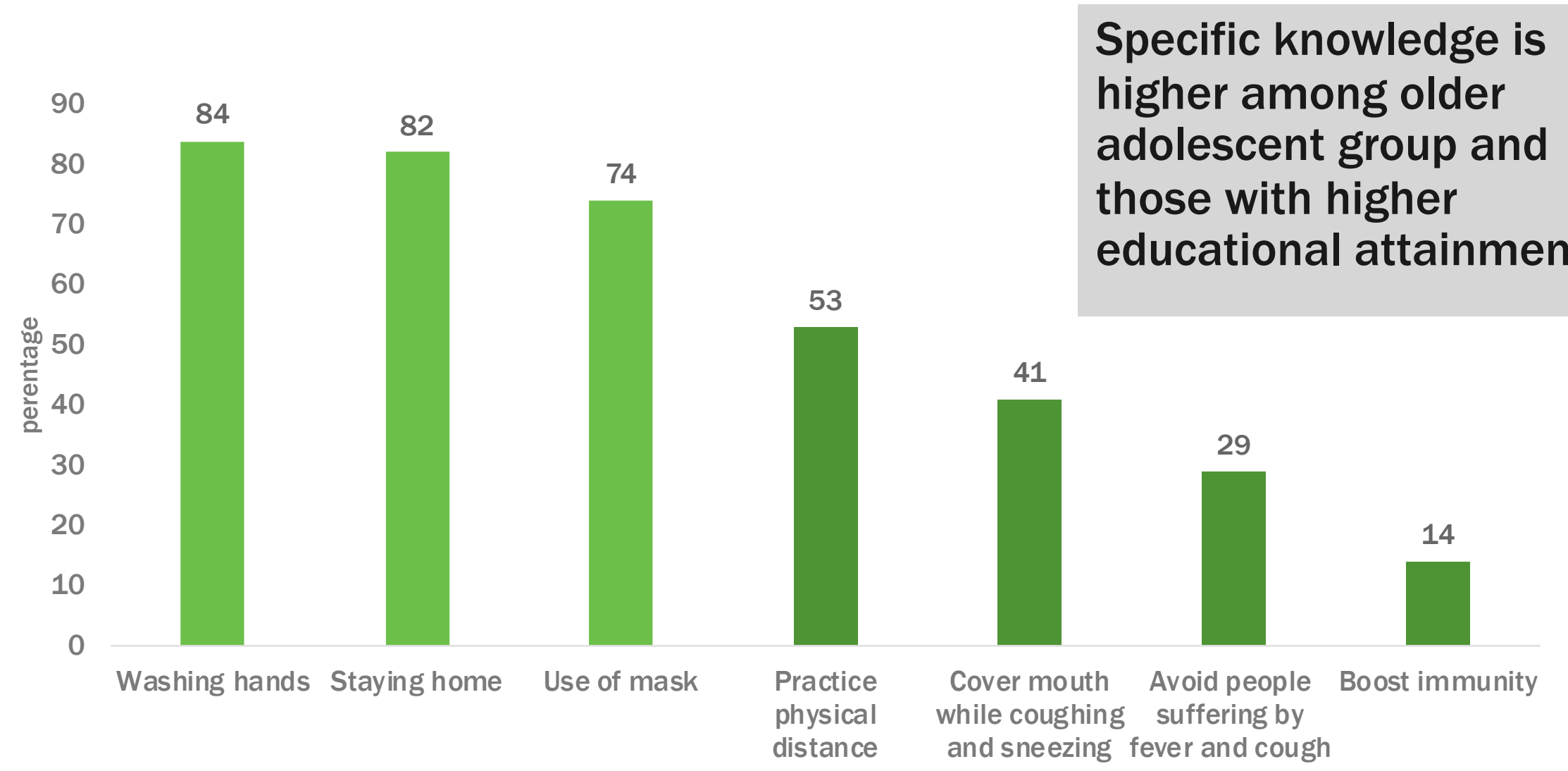

Common and universal knowledge

Specific knowledge 


\section{Changed practices (compared to previous month) for prevention of COVID-19}

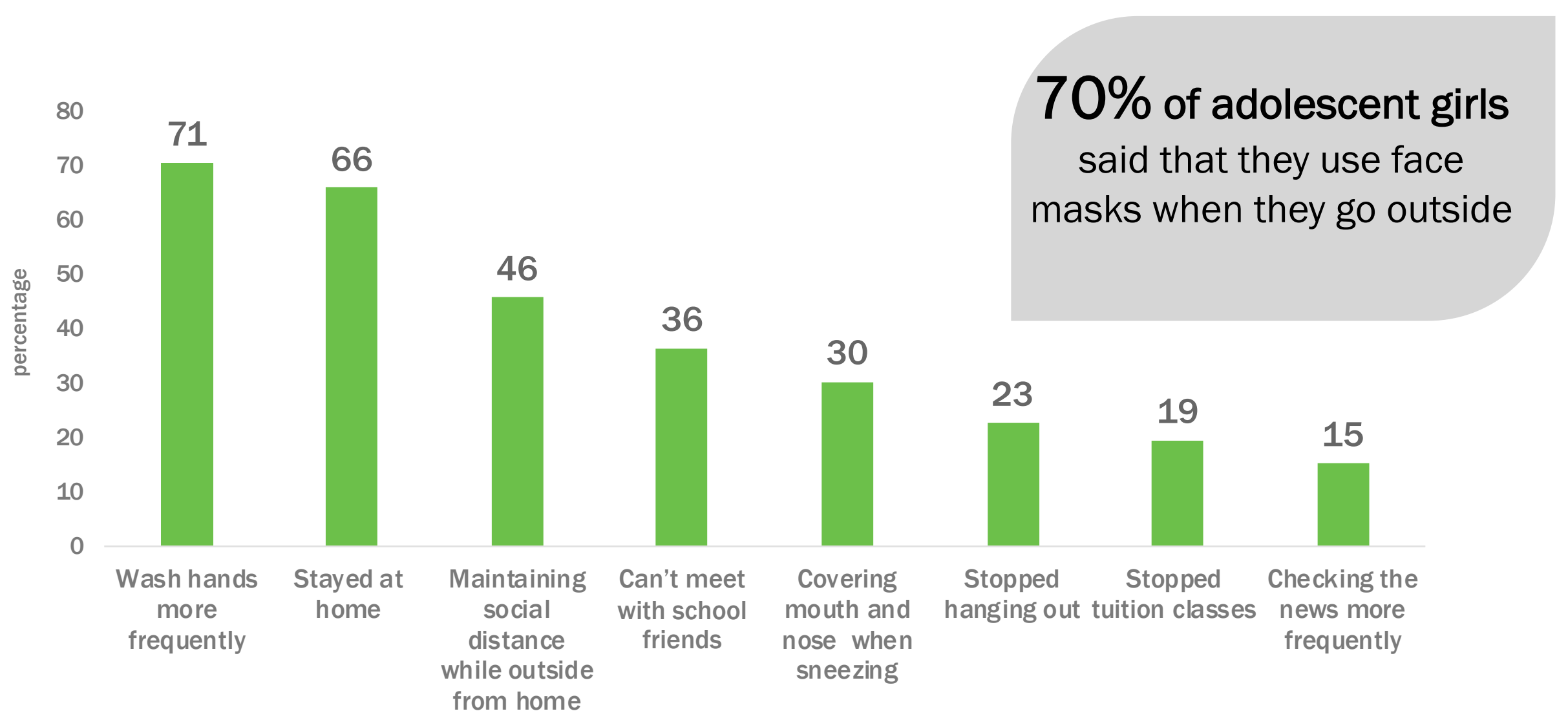

$70 \%$ of adolescent girls

said that they use face masks when they go outside 


\section{Risk perception: Can you be infected by coronavirus?}

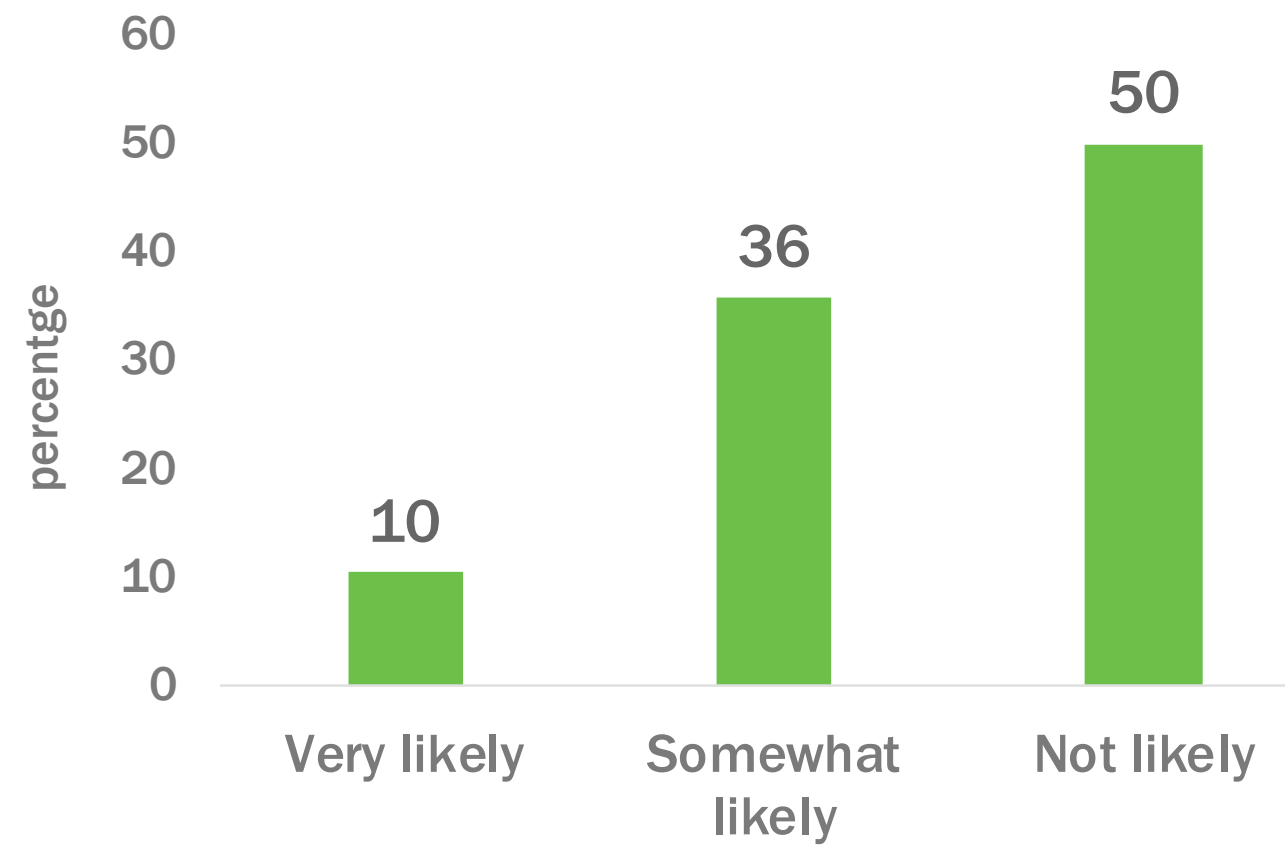

Younger girls are less likely to say they are at high risk compared with older girls (6\% for aged $10-15$ vs. $18 \%$ for aged $16-21$ )

likely 


\section{What steps should be taken if showing COVID-19 symptoms?}

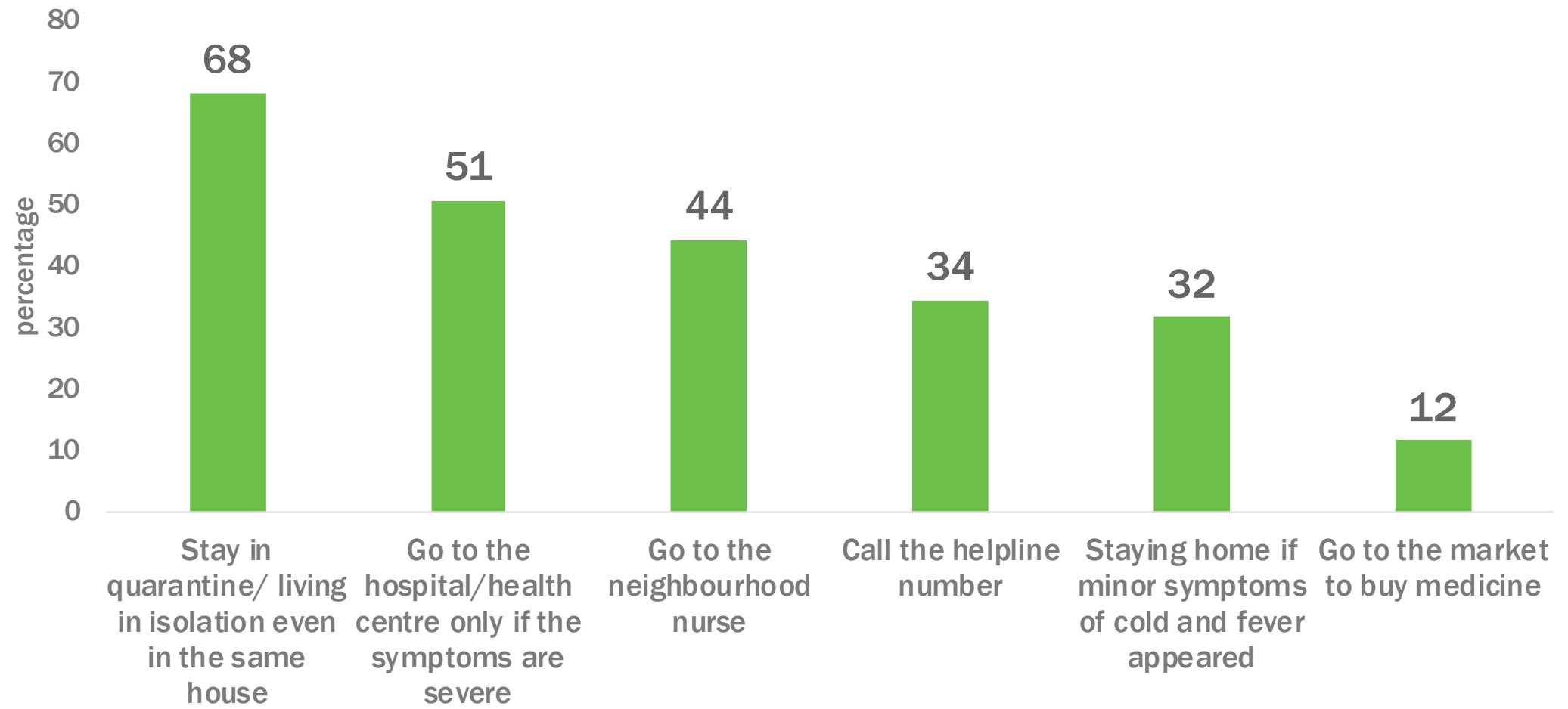




\section{Social distancing during lockdown}

Mean days staying home per week

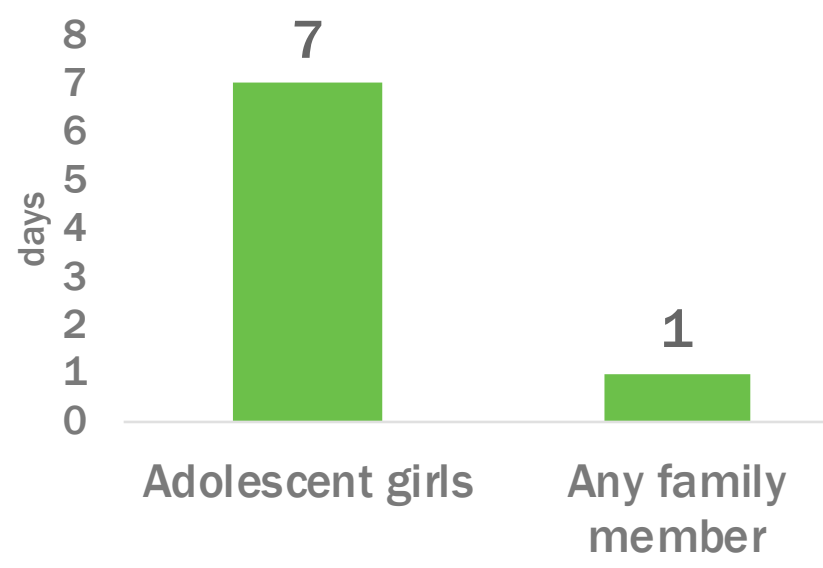

Went out in past 24 hours

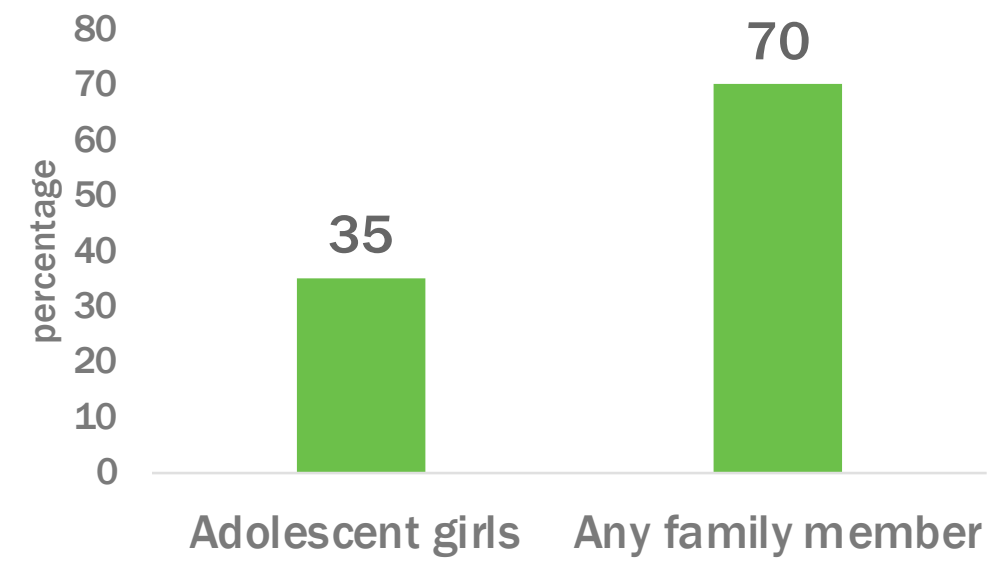




\section{Effects of and coping with the response to COVID-19}




\section{Income status and food security}
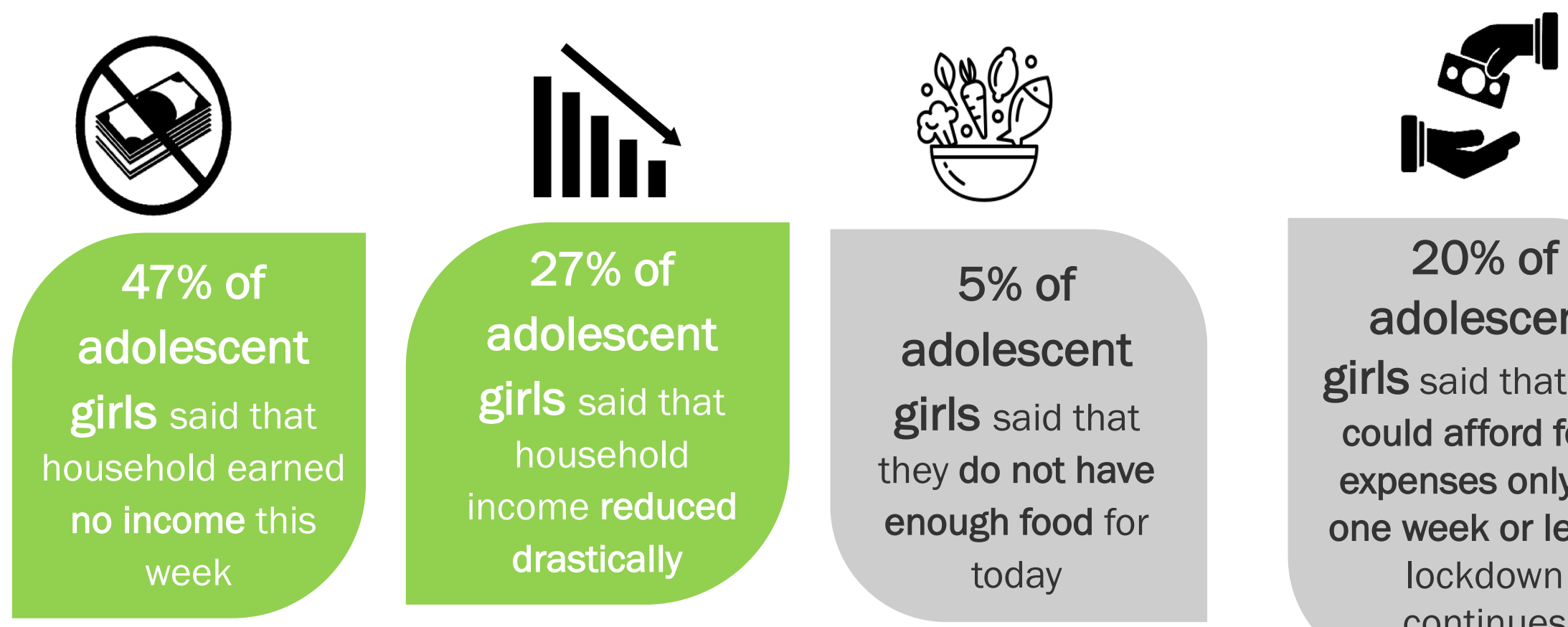

$20 \%$ of adolescent girls said that they could afford food expenses only for one week or less if

lockdown continues

\footnotetext{
Essential items for households

$\checkmark$ 90\% of adolescent girls mentioned food (rice, pulses and/or groceries)

$\checkmark$ 68\% mentioned soap to wash hands frequently

$\checkmark$ 41\% mentioned medicine
} 


\section{How do you study during the time of lockdown?}

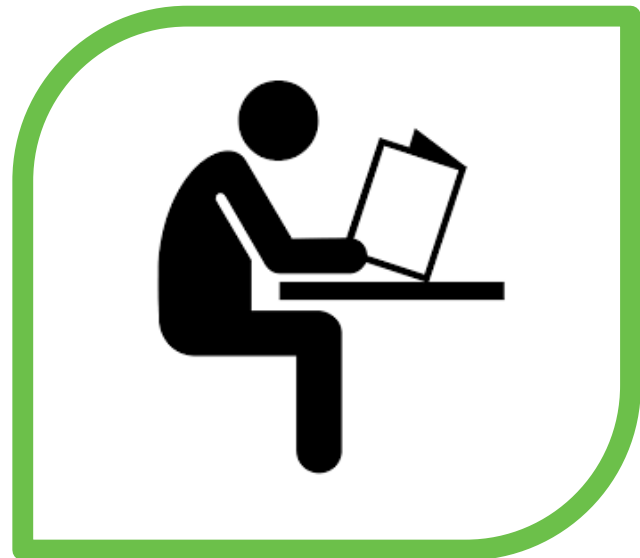

Among the in-school girls $90 \%$ reported studying by herself or studying under the supervision of other family members at home

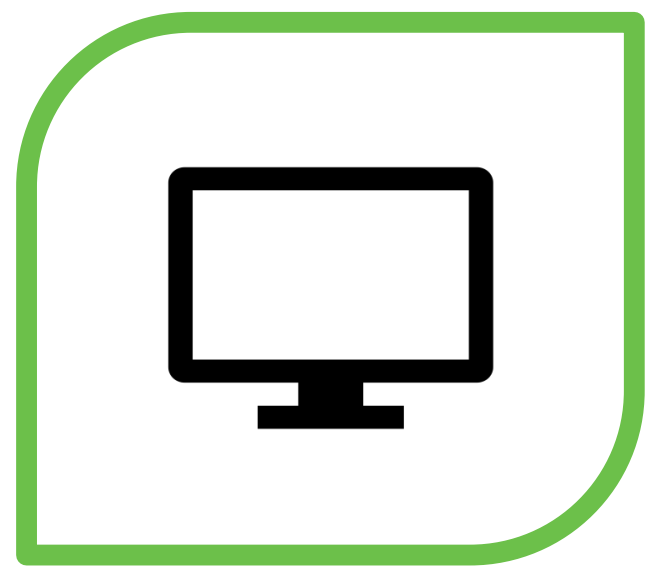

Among the in-school girls $26 \%$ reported following the classes broadcast on television 


\section{Health and social impacts}

$10 \%$ of adolescent girls $(n=85)$

mentioned having any sick or ill person in her house.
- $41 \%$ of sick family members took medicines from the local pharmacy

- $22 \%$ of sick family members visited a doctor

- One third of the sick family members did not take treatment
$53 \%$ of adolescent girls reported increased workload in patient care-taking

$\checkmark 60 \%$ of adolescent girls reported experiencing depression sometimes during the lockdown

$\checkmark 15 \%$ of adolescent girls reported experiencing depression most of the time during the lockdown 


\section{Experiences of domestic violence during lockdown}

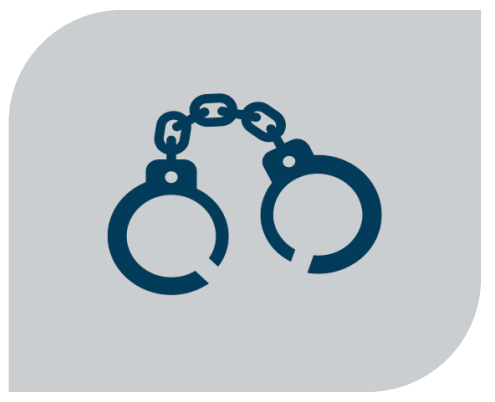

$18 \%$ of the adolescent girls reported experiencing domestic

\section{violence}

\section{Older girls aged} 16-21 reported experiencing more violence compared with younger girls aged $10-15$ ( $32 \%$ vs $11 \%$ )

\section{Married girls} reported experiencing more violence compared with unmarried girls (35\% vs $16 \%$ )

$\mathbf{2 8} \%$ of the adolescent girls mentioned they observed increased domestic violence in their surroundings during lockdown

Older girls aged 16-21 reported observing more violence compared with younger girls aged 1015 (46\% vs $19 \%)$
Married girls reported observing more violence compared with unmarried girls (53\% vs $25 \%$ ) 


\section{Recommendations (1)}

\section{Strengthen public education campaigns on:}

- Asymptomatic spread

- Social distancing practices

- Help-seeking for suspected infection, such as calling hotline for advice and staying home/self-isolating if one has mild symptoms

- Since younger adolescent girls (aged 10-15) seem to have comparatively less knowledge about COVID-19, the education system should tap into awareness messaging in girls' life skills curriculum 


\section{Recommendations (2)}

Provide Social Protection and Safety Net for the most vulnerable

- Address the impacts of income loss and food security, with special attention to adolescent girls and women as increased household work and caring for ill family members have been reported by adolescent girls.

- It is critical that assistance is provided to women in order to help them cope with these challenges.

- Provide access to remote mental health services protection from violence. 


\section{Team Members}

\begin{tabular}{|l|l|}
\hline $\begin{array}{l}\text { Ubaidur Rob, Senior Associate \& } \\
\text { Country Director, BD }\end{array}$ & Forhana Noor, Program Officer, BD \\
$\begin{array}{l}\text { Sajeda Amin, Senior Associate, New } \\
\text { York }\end{array}$ & Surojit Kundu, Program Officer, BD \\
Masuma Billah, Senior Program & Iqbal Ehsan, Program Officer, BD \\
Officer, BD & \\
Sigma Ainul, Senior Program Officer, & Eashita Farzana Haque, Assistant \\
BD & $\begin{array}{l}\text { Program Officer, BD } \\
\text { Irfan Hossain, Senior Program }\end{array}$ \\
Officer, BD & Saddam Hossain, Research Officer, \\
& BD \\
& Mehnaz Manzur, Research Officer, \\
& $B D$ \\
\hline
\end{tabular}

For more information contact Sajeda Amin (samin@popcouncil.org) 